\title{
Guy de Maupassant, Une vie
}

\section{Maria Emanuela Raffi}

\section{(2) OpenEdition}

\section{Journals}

\section{Edizione digitale}

URL: http://journals.openedition.org/studifrancesi/5406

DOI: 10.4000/studifrancesi.5406

ISSN: 2421-5856

\section{Editore}

Rosenberg \& Sellier

\section{Edizione cartacea}

Data di pubblicazione: 1 dicembre 2016

Paginazione: 556

ISSN: 0039-2944

\section{Notizia bibliografica digitale}

Maria Emanuela Raffi, « Guy de Maupassant, Une vie », Studi Francesi [Online], 180 (LX | III) | 2016,

online dal 01 janvier 2017, consultato il 18 septembre 2020. URL : http://journals.openedition.org/ studifrancesi/5406 ; DOI : https://doi.org/10.4000/studifrancesi.5406

\section{Questo documento è stato generato automaticamente il 18 settembre 2020.}

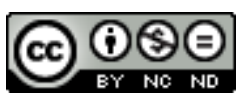

Studi Francesi è distribuita con Licenza Creative Commons Attribuzione - Non commerciale - Non opere derivate 4.0 Internazionale. 


\title{
Guy de Maupassant, Une vie
}

\author{
Maria Emanuela Raffi
}

\section{NOTIZIA}

GUY DE MAUPASSANT, Une vie, texte intégral, dossier par Delphine Morel Vacher, lecture d'image par Agnès Verlet, Paris, Gallimard, 2015, pp. 5-269 + 271-342.

1 Si segnala questa nuova edizione, per la collana «Folioplus classiques», di Une vie di Maupassant, accompagnata da un dettagliato dossier didattico di Delphine Morel Vacher e da un breve saggio di Agnès Verlet, Du tableau au texte, dedicato alla Mer orageuse o La Vague, grande quadro di Courbet del 1869. Messa in parallelo con le descrizioni della natura e del mare della Normandia molto presenti nell'opera di Maupassant, la tela di Courbet, più volte eseguita dal pittore in numerose repliche, rivela l'affinità dei due artisti, affinità confortata, oltre che dall'esperienza degli stessi spettacoli naturali, anche dalla concreta visione, da parte di Maupassant, del lavoro di Courbet nel suo atelier di Étretat. 